\title{
The influence of different diets on haemocytes of adult worker honey bees, Apis mellifera
}

\author{
Bożena SZYMAŚa*, Andrzej JĘDRUSZUK ${ }^{\mathrm{b}}$ \\ a Department of Useful Insect Breeding, University of Agriculture, Wojska Polskiego str. 71c, \\ 60-625 Poznañ, Poland \\ b Department of Bee Diseases, National Veterinary Research Institute, Poznańska str. 35, \\ 62-020 Swarzędz, Poland
}

(Received 1 May 2001; revised 23 July 2001; accepted 27 June 2002)

\begin{abstract}
The influence of different diets on the haemolymph of adult honeybee workers was examined. The laboratory experiments took place in early summer. There were three experimental groups fed with one of the following diets: pollen with sugar, pollen substitute alone, or sugar. A sample of haemolymph was taken from 7-8 day old bees and numbers of haemocytes of each type (plasmatocytes, granular haemocytes, and other types of haemocytes pooled together) were recorded and the metabolic activity of haemocytes was observed. A lack of protein caused a significant increase in the percentage of granular haemocytes, a significant decrease of other types and a lower metabolic activity. The examined pollen substitute caused a decrease of total haemocyte count. The decrease in the metabolic activity of haemocytes was lower than without protein.
\end{abstract}

Apis mellifera / diet / haemocyte / adult worker

\section{INTRODUCTION}

Haemocytes are of fundamental importance in the preservation of an insect homeostasis, especially in regards of cellular defense reactions and management of nutritional elements (Gliński and Jarosz, 1995). These cells circulating in haemolymph are easily accessible to evaluate an insect homeostasis and analysis of haemocytes enables the estimation of the influence of different external factors, such as pathogens, medicines, pesticides, and environmental pollutants, which all can affect insects homeostasis (Gliński and Grzegorczyk, 1995). Such analysis should be particularly useful to assess diet and therapeutical treatments for honeybees as well as chemicals for plant pro- tection recommended as not harmful to bees. Examination of haemocytes may also be useful to determine the effects of environmental factors on a range of immune parameters of cellular system of honeybee haemolymph. Total haemocyte counts (THC), differential haemocyte counts (DHC) and metabolic activity are the most important attributes of this system and are indicators of its functional efficiency. Metabolic activity was used as an indirect estimation of ability of cells to phagocytose (Gliński and Klimont, 1987b).

In natural conditions, the sources of food for bees are nectar, honeydew and pollen. Proteinaceous supplements are used as pollen substitutes to supplement the protein diet of bees. The influence of differential diet on the

\footnotetext{
* Correspondence and reprints

E-mail: beszymas@au.poznan.pl
} 


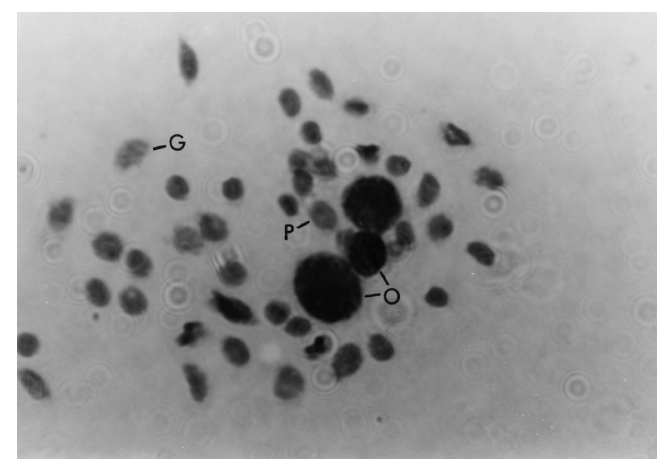

Figure 1. Haemocytes of young worker honey bees (magnification $1000 \times$ ). $\mathrm{G}$ - granular haemocytes; $\mathrm{P}$ - plasmatocytes; $\mathrm{O}$ - other haemocytes.

cellular components of haemolymph is not yet known in honeybees. The aim of this experiment was to estimate the influence of proteinaceous and non-proteinaceous food composition on haemocytes in the honeybee.

\section{MATERIALS AND METHODS}

The studies were carried out in the years 1997 , 1998 and 1999. The observations were made in early summer. The experimental groups of bees (Apis mellifera L.) were fed with the following components: bee pollen with sugar candy (natural proteinaceous food, total protein level $=20 \%$ ), pollen substitute, and sugar candy only (nonproteinaceous food). The pollen substitute was a multicomponent food supplemented with methionine and lysine amino acids to reach the level found in bee pollen, and a total protein content of $20 \%$ similar to that of the bee pollen used. This pollen substitute was made of the following raw materials: potato protein $(32 \%)$, extracted rape meal $(6 \%)$, soya powder (18\%), yeast Candida utilis $(6 \%)$, wheat meal $(14.8 \%)$, maize grits $(17.5 \%)$. The basic components were supplemented with vitamin and mineral mixes Polfamix W (1.4\%), vitamin preparation (0.3\%), amino acids (methionine and lysine), and lactic acid to lower the $\mathrm{pH}$ of the pollen substitute to 5.5 as that of the bee pollen used. All components were ground to particles smaller than $150 \mu \mathrm{m}$. The energy source in the diet was soybean oil (3.5\%) and rape lecithin $(0.5 \%)$ as emulsifier. The fat fraction in the substitute was stabilized with an antioxidant (commercial name Rendox ${ }^{\circledR}$ ). Finally the pollen substitute was mixed with powdered sugar $(1: 1 \mathrm{w} / \mathrm{w})$.
The total protein content in the diets was determined by the Kjeldahl's method multiplying the nitrogen amount by 6.25 . The amino acids were identified using an AAA339 analyzer (Mikrotechna, Czeck Republic) after a hydrolysis of the samples in $6 \mathrm{n} \mathrm{HCl}$ at $105^{\circ} \mathrm{C}$ for $23 \mathrm{~h}$. Amino acids with sulphur were determined after their oxidation and fixation with performic acid. On the basis of amino acid composition, the index of each diet was calculated according to Chemical Score (Block and Mitchell, 1946) and Essential Amino acids index (Oser, 1952).

In each experimental group, one-day-old worker bees were fed for 7-8 days ad libitum in incubators at $28{ }^{\circ} \mathrm{C}$ and $40 \% \mathrm{RH}$. Young bees were kept without queens in small polystyrene cages $(70 \mathrm{~mm} \times 80 \mathrm{~mm} \times 120 \mathrm{~mm})$. Each group in each year consisted of 5 times 150 bees each, which originated from one queen and one colony. From each group, bees were randomly selected after 7 8 days and their haemocytes were examined in haemolymph drawn from the sinus dorsalis of their circulatory system. Total haemocyte counts in undiluted haemolymph were determined using a Bürker's haemocytometer. Every year, 7 to 21 observations of randomly selected bees were carried out for each diet; which gave a total of 3738 observations over 3 years.

Differential haemocyte counts were evaluated in smears of haemolymph stained with Wright's stain according to the method of Gilliam and Shimanuki (1971). Following Jędruszuk (1997), haemocytes were classified as plasmatocytes, granular haemocytes, or other (all other types of haemocytes pooled together; Fig. 1). Plasmatocytes were small round cells with compact, round nuclei and thin, hyaline neutrophilic or pale-basophilic cytoplasm or in which the cytoplasm was not visible. Granular haemocytes were large oval or ellipsoidal cells with granular nuclei and vacuolated cytoplasm. Their cytoplasm was neutrophilic or pale-basophilic and occupied most of the cell. Other types of haemocytes were large (from several times to twelve or more times bigger than the plasmatocytes). They made less than $10 \%$ of the total number of haemocytes. The percentage of haemocytes of each type was calculated in each sample. From 8 to 36 smears of haemolymph were examined for each diet every year to give a total of 50 to 70 over three years.

Metabolic activity was observed in the haemocytes using a modified Nitro Blue Tetrazolium (NBT) test (Gliński and Klimont, 1987b). The method is based on the reduction of nitro blue tetrazolium to phormasane in haemocytes showing signs of metabolism indicating that they are active in phagocytosis. A drop of haemolymph was mixed with $2.0 \mu \mathrm{L}$ of the incubation solution 
Table I. Cell content of haemolymph of worker honey bees raised in standard free-flying colonies and in incubator on different diets.

\begin{tabular}{|c|c|c|c|c|}
\hline \multirow[b]{2}{*}{ Group } & & \multicolumn{3}{|c|}{ Bioassay with special diet (7-8 d old bees; summary of 1997-1999) } \\
\hline & $\begin{array}{l}\text { 5-d old workers in } \\
\text { standard colonies } \\
(1997)\end{array}$ & Diet with bee pollen & $\begin{array}{l}\text { Diet with pollen } \\
\text { substitute }\end{array}$ & Diet with sugar only \\
\hline $\begin{array}{l}\text { Total haemocyte } \\
\text { Count (per } \mu \mathrm{L})\end{array}$ & $\begin{array}{c}15172 \pm 4507 \\
n=50\end{array}$ & $\begin{array}{c}15287 \pm 8984 \mathrm{ab}^{\dagger} \\
\mathrm{n}=38\end{array}$ & $\begin{array}{c}14231 \pm 5039 b \\
n=38\end{array}$ & $\begin{array}{c}16574 \pm 4446 a \\
n=37\end{array}$ \\
\hline $\begin{array}{l}\text { Plasmatocytes }(\%) \\
\text { Granular haemocytes } \\
(\%)\end{array}$ & $\begin{array}{l}85.3 \pm 17(n=48) \\
13.3 \pm 16.8(n=48)\end{array}$ & $\begin{array}{l}76.4 \pm 23.1 b(n=50) \\
21.1 \pm 23.5 b(n=50)\end{array}$ & $\begin{array}{l}86.2 \pm 14.6 \text { a }(n=70) \\
12.0 \pm 14.7 \text { c }(n=70)\end{array}$ & $\begin{array}{c}63.8 \pm 29.6 c(n=63) \\
35.1 \pm 29.8 a(n=63)\end{array}$ \\
\hline $\begin{array}{l}\text { Other haematocytes } \\
(\%)\end{array}$ & $1.4 \pm 1.4(\mathrm{n}=48)$ & $2.5 \pm 2.5 \mathrm{a}(\mathrm{n}=50)$ & $1.8 \pm 2.3 \mathrm{a}(\mathrm{n}=70)$ & $1.1 \pm 1.6 \mathrm{a}(\mathrm{n}=63)$ \\
\hline $\begin{array}{l}\text { Metabolic activity } \\
\text { (\% positive with nitro- } \\
\text { blue tetrazolium test) }\end{array}$ & $* 3.5 \pm 1.8(\mathrm{n}=24)$ & $2.6 \pm 2.3 \mathrm{a}(\mathrm{n}=96)$ & $1.7 \pm 1.9 b(\mathrm{n}=101)$ & $0.9 \pm 1.3 \mathrm{c}(\mathrm{n}=109)$ \\
\hline
\end{tabular}

\footnotetext{
$\dagger$ Means \pm sd; values followed by different letter in each line are significantly different at $P=0.05$ based on Fisher's LSD procedure.

* indicates significant differences $(P<0.05)$ between the values of the bees from the standard colonies and those from bees fed on pollen substitute based on a Student's $t$-test.
}

$(0.2 \%$ of NBT dissolved in $0.85 \% \mathrm{NaCl}$ and phosphorane buffer $\mathrm{pH}$ 7.4) on a microscope slide. Then the mixture was incubated in a water bath for $15 \mathrm{~min}$ at $36{ }^{\circ} \mathrm{C}$. Afterwards, the mixture was incubated in a water bath at room temperature for $15 \mathrm{~min}$. During incubation, the mixture was stirred a few times by delicately tilting the glass slide. After incubation, the mixture was smeared on the glass slide and desiccated. The smear was then stained in Wright's stain and observed under $1000 \times$ microscope magnification. The cells containing blue grains of phormasane were counted and recorded as a percentage of the total number of haemocytes. From 11 to 70 examinations of NBTtest were carried out every year for each diet resulting in a total of 96 to 109 observations over 3 years.

The number of haemocytes were analyzed after a square root transformation and the proportion of granular haemocytes and plasmatocytes after an Arcsin $\sqrt{ }$ transformation to stabilize the variance among groups (Bliss, 1937). The years, diets, the interaction between years and diets were taken into consideration in the analysis of variance. I assumed a mixed model with a random effect for year. When the $\mathrm{F}$ tests were significant $(P<0.05)$, means were separated by applying the Fischer's least significant difference procedure. Untransformed mean values are given in Table I.

Additionally, in order to get some baseline data on the haemocyte system in worker bees, we used 5-day old workers originating from standard colonies in 1997. To that end, several hundred emerging bees were marked and placed in standard honeybee colonies and, 5 days later, about 50 individuals were randomly selected from that group and the characteristics of their haemocyte system were determined using the same methods as above. The results were compared with those obtained from the workers fed with the pollen substitute using Student's $t$-test.

\section{RESULTS}

The characteristics of haemocytes in workers living in standard colonies in the field in 1997 are presented in Table I. In the haemolymph of bees fed with non-proteinaceous food, we observed a tendency for an increase in total haemocyte count, a significant increase in the percentage of granular haemocytes, a significantly lower amount in other types of haemocytes and a lower metabolic activity of haemocytes compared with the haemolymph of bees fed with pollen and pollen substitute (Tab. I).

In the haemolymph of bees fed with pollen substitute, there was a lower total haemocyte count, a significantly higher percentage in plasmatocytes, a significant decrease of granular haemocytes, and a significant decrease of 
metabolic activity of haemocytes compared with the haemocyte system of bees fed with pollen.

In honeybees fed sugar only, there was a smaller percentage of other types of haemocytes and an increase of granular haemocytes, which suggest a decrease in the differentiation of haemocytes and a possible mobilization of older granular haemocytes which may act as storage cells in the insect.

The above follows from the Fisher LSD procedure carried out for selected average pairs. Regarding the total number of haemocytes (THC), significant differences were found between the proteinless diet and the diet with pollen substitute. For the metabolic activity of haemocytes (NBT test) and for the percentage of granular haemocytes and plasmatocytes, significant differences were found between all feeding groups. For the 'other' category of haemocytes, no significant differences between the diets were found.

\section{DISCUSSION}

The haemocyte system from standard bee colonies and from incubator-raised bees with proteinaceous diet based on pollen substitute showed a similar picture with similar proportions of each type of haemocytes. But the total number of haemocytes in bees fed on pollen substitute was lower and the metabolitic activity of these haemocytes was less in comparison to bees raised in bee colonies in the open. In the haemolymph of bees fed on non-proteinaceous diet, there was a greater proportion of granular haemocytes and a smaller proportion of plasmatocytes in comparison to the haemolymph of bees from standard bee colonies. Furthermore, in the group without protein in their diet, there was a greater total number of haemocytes and a smaller number of metabolically active haemocytes when compared with the haemocyte system of the bees raised in standard bee colonies. In the haemolymph of incubator-raised bees fed on pollen, the total number of haemocytes was similar to that of bees raised in standard colonies in the open. The metabolic activity of haemocytes of workers fed pollen in the incubator was also more similar to that of bees raised in standard colonies compared to that of the worker bees fed other diets. In the haemolymph system of incubator-raised bees fed on pollen, there was a higher proportion of granular haemocytes and of haemocytes of the 'other' category. There was also a smaller proportion of plasmatocytes in comparison to the haemolymph of bees raised in standard colonies. The high value of the standard deviation (s.d. = 8984) in the total number of haemocytes in the experimental group fed on pollen might have resulted from the botanical diversity of the pollen used in the successive years of experiment. There were few significant differences in the haemolymph of incubatorraised bees fed with natural pollen versus pollen substitute.

The results show that feeding bees with a non-proteinaceous diet may activate the mechanism compensating for a lack of protein in the haemolymph of the bee. The total number of haemocytes increased, as did the proportion of older haemocytes which may be nutrient cells, while there were fewer young haemocytes as described by other authors as plasmatocytes or prohaemocytes (Wienands et al., 1987; Wienands and Madel, 1988; van Steenkiste, 1988; Papadopoulou-Karabela et al., 1993). Our results are in agreement with those of previous studies that found that plasmatocytes are the most numerous cells in haemolymph of young honeybee from free-flying colonies (Jędruszuk, 1998a,1998b, 1998c). They also confirm observations made earlier by Wienands et al. (1987) and van Steenkiste (1988). However, examination of plasmatocytes only may not be sensitive enough, as the next consequence of a lack of protein in the diet was a large decrease in the proportion of metabolically active cells, which suggests a reduced ability to phagocytose. Gliński and Klimont (1987a, 1987b) observed a decrease in total haemocyte count, but no change in the metabolic activity of haemocytes in the haemolymph of honeybees infested with the mite Varroa destructor. The present experiment shows that a lack of protein in the diet can cause greater disturbances in the functioning of the cellular system of the haemolymph than parasitism by $V$. destructor. So far, the problems referring to the diversity of the honey bee haemocytes have not been discussed in any scientific sources, therefore, the 
results of the presented work cannot be compared with the results of other authors.

Natural proteinaceous food is an important factor in the functioning of the cellular system of honeybee haemolymph. Our results indicate that a lack of protein in the diet causes considerable changes in the functioning and structure of the cellular system of the haemolymph. The pollen substitute we used appeared to be a valuable proteinaceous food which approximated the pollen; however, it did cause some changes in the haemocytes of honeybee workers. Our results suggest that analysis of the cellular system of the haemolymph could be a relatively sensitive diagnostic tool for the evaluation of the physiological state of an insect.

\section{ACKNOWLEDGMENTS}

We express our sincere thanks to Gudrun Koeniger for her cordial help and remarks in the correction of our manuscript. Our most cordial thanks to Bernard Vaissière for the linguistic correction of our paper.

Résumé - L'influence de divers régimes sur les hémocytes des ouvrières adultes de l'abeille domestique (Apis mellifera). Nous avons étudié l'influence de la composition d'une nourriture protéinée et non protéinée sur les hémocytes de l'abeille. Nos expériences ont été faites aux début de l'été en 1997, 1998 et 1999. Nous avons nourri ad libitum trois groupes d'abeilles avec l'un des régimes suivants : pollen et sucre, succédané de pollen et sucre, et sucre seulement. Ces abeilles ont été maintenues en étuve à $28{ }^{\circ} \mathrm{C}$ et $40 \% \mathrm{RH}$ et, à l'âge de 7-8 jours, elles ont été anesthésiées, puis des échantillons d'hémolymphe ont été prélevés dans leur sinus dorsalis. Nous avons déterminé le nombre total d'hémocytes et le pourcentage d'hémocytes pour chacune de 3 catégories (plasmatocytes, hémocytes granuleux et autres types d'hémocytes). La réaction des hémocytes au test NBT (nitro-bleu de tétrazolium) a été prise comme mesure de l'activité métabolique des hémocytes. Les résultats obtenus montrent que la nourriture protéique naturelle constitue un facteur important dans le fonctionnement du système cellulaire de l'hémolymphe de l'abeille. Le succédané de pollen utilisé semble avoir une valeur proche de celle du pollen naturel, mais il a néanmoins entraîné une diminution significative du nombre total d'hémocytes et de leur activité métabolique. Le manque de protéines a provoqué des changements importants dans la structure et le fonctionnement du système cellulaire de l'hémolymphe. On suppose que le régime sans protéines oblige l'organisme à compenser le manque de protéines dans l'hémolymphe par l'augmentation du nombre d'hémocytes et par l'accroissement du pourcentage des hémocytes les plus vieux. Cependant la diminution sensible des cellules métaboliquement actives que nous avons observée peut influencer la réduction de leur activité phagocytaire. Ces résultats suggèrent que l'analyse du système cellulaire de l'hémolymphe pourrait constituer un élément de diagnostic assez sensible pour estimer l'état physiologique des insectes.

\section{Apis mellifera / régime alimentaire / hémocyte / ouvrière / hémolymphe}

Zusammenfassung - Der Einflu $\beta$ unterschiedlicher Nahrung auf Hämozyten von erwachsenen Arbeitsbienen (Apis mellifera). Die Versuche wurden im Frühsommer 1997, 1998 und 1999 durchgeführt. In 3 Versuchen fütterte man Bienengruppen ad libitum mit einem der genannten Futtermittel: Pollen mit Zucker, Pollenersatz oder mit Zucker. Die Bienen wurden im Brutschrank bei $28{ }^{\circ} \mathrm{C}$ und $40 \% \mathrm{RH}$ gehalten. Von 7-8 Tage alten Bienen wurde nach der Betäubung die Hämolympheprobe aus dem Sinus dorsalis entnommen. Es wurde die Gesamtzahl der Hämozyten und das Differentialhämozytenbild (Plasmozyte, granulöse Hämozyte und andere Hämozyten) berechnet. Während des Experiments wurde auch die NBT (Nitro Blue Tetrazolium) Reaktion des Hämozyten als ein $\mathrm{Ma} \beta$ für metabolische Aktivität gemessen.

Die Ergebnisse zeigen, dass das natürliche Proteinfutter ein wichtiger Faktor für das Funktionieren des Hämolymphezellensystems der Honigbiene ist. Der untersuchte Pollenersatz scheint eine wichtige, mit dem natürlichen Pollen vergleichbare Proteinnahrung zu sein, obwohl sie eine Minderung der allgemeinen Hämozytenzahl und der metabolischen Aktivität bewirkt. Mangel an Protein führt $\mathrm{zu}$ erheblichen Störungen in der Struktur und in dem Funktionieren des Hämolymphezellensystems. Es wird vermutet, dass die Diät ohne Protein den Organismus dazu zwingt, den Mangel an Protein in der Hämolymphe zu kompensieren, indem die Zahl der Hämozyten und die Prozentzahl der älteren Hämozyten zunimmt. Die beobachtete erhebliche Abnahme der metabolisch aktiven Zellen kann jedoch auch einen Einfluss auf die Reduktion ihrer Phagozytenaktivität haben.

Das Experiment läßt uns vermuten, daß die Analyse des Zellensystems der Hämolymphe ein ziemlich empfindliches diagnostisches Element für die Beurteilung des physiologischen Zustands von Insekten sein könnte.

Unterschiedliche Diät / Hämozyten / erwachsene Arbeiterinnen / Apis mellifera 


\section{REFERENCES}

Bliss C.I. (1937) Plant Protection (Leningrad) 12, 67.

Block R.J., Mitchell H.H. (1946) The correlation of the amino acid composition of proteins with their nutritive value, Nutr. Rev. 16, 249-255.

Gilliam M., Shimanuki H. (1971) Blood cells of the worker honeybee, J. Apic. Res. 10, 79-85.

Gliński Z., Klimont S. (1987a) Wpływ inwazji Varroa jacobsoni Oud. na elementy komórkowe hemolimfy pszczół robotnic, Apis mellifera L., Medycyna Wet. 43, 546-549.

Gliński Z., Klimont S. (1987b) Aktywność hemocytów pszczół robotnic w przebiegu naturalnego zarażenia Varroa jacobsoni Oud., Medycyna Wet. 43, 664-667.

Gliński Z., Grzegorczyk K. (1995) Cellular Defense Reactions in the Honeybee in Environment Non-Polluted with Heavy Metals, Ann. Univ. Mariae Curie Sktodowska, DD 50, 131-137.

Gliński Z., Jarosz J. (1995) Mechanical and biochemical defences of honey bees, Bee World 76, 110-118.

Jędruszuk A. (1997) Uproszczona systematyka komórek hemolimfy pszczoły miodnej (Apis mellifera L.) Materiały XIII Naukowej Konferencji "Warroza pszczół i gospodarka pasieczna", Olsztyn-Kortowo 12.05.1997 r., pp. 28-30.

Jędruszuk A. (1998a) Age-dependence of metabolic activity of haemocytes in haemolymph of adult worker honey bees from spring-summer generation, Pszcz. Zesz. Nauk. XLII 2, 41-42.

Jędruszuk A. (1998b) Total haemocyte counts in haemolymph of adult worker honey bees (Apis mellifera L.) from spring-summer and autumnwinter generations, Pszcz. Zesz. Nauk.XLII 2, 43-44.

Jędruszuk A. (1998c) Wstępna analiza zmian obrazu hemolimfy pod wpływem wieku u pszczół robotnic A. mellifera, XXXV Nauk. Konf Pszczel. Puławy 11-12 marca 1998, pp. 32-33.

Oser B.L. (1952) Method for integrating essential amino acid content in the nutritional evaluation of protein, J. Am. Diet Assoc. 27, 396-399.

Papadopoulou-Karabela K., Iliadis N., Liakos V. (1993) Haemocyte changes in honeybee (Apis mellifera L) artificially infected by Pseudomonas aeruginosa, Apidologie 24, 81-86.

van Steenkiste D. (1988) De hemocyten van de honigbij (Apis mellifera L.): typologie, bloedbeeld en cellulaire verdegingsreacties, Proefschrift, Doctor in de Wetenschappen, Rijksuniversiteit Gent, 1988.

Wienands A., Madel G. (1988) Hämozyten der Honigbiene, Apis mellifera und ihre Veränderungen durch Varroatose (Hymenoptera: Apidae), Entomol. Gen. 14, 81-92.

Wienands A., Strick H., Madel G. (1987) Varroatosis: haemocytic and bacteriological aspects of the haemolymph of Apis mellifera L. (Hymenoptera, Apidae), Zentralbl. Bakteriol., Mikrobiol. und Hyg. 265, 489. 